\title{
Optimization of cereal-legume blend ratio to enhance the nutritional quality and functional property of complementary food
}

\author{
Helen Walle $^{1 *}$ and Demewez Moges ${ }^{1}$ \\ ${ }^{1}$ Faculty of Chemical and Food Engineering, Bahir Dar Institute of Technology, Bahir Dar University
}

\begin{abstract}
This study investigated the effect of different cereal-legume blending ratios on nutritional quality and functional property of different blends. The legumes and steeped cereals were cleaned, minimally roasted, dehulled, milled and sifted separately. A single-factor experiment with three levels of the factor (cereal: legume ratio 85:15, 75:25 and $65: 35$ coded as B1, B2 and B3, respectively) with two replications were used to conduct the experiment. The collected data were subjected to analysis of variance using SPSS statistical software and compared with the recommended values for the age group of 6-24 months. Mean separation result showed that protein, fat, energy, crude fibre and ash contents were significantly $(\mathrm{p}<0.05)$ different among the blends where B3 revealed higher values. Protein contents of B2 and B3, ash and fiber content of the three blends, as well as energy value of B3 were within the recommended levels. However, none of the blends met the recommended fat content. Calcium, zinc and iron content of the blends increase as the proportion of legumes increase, but only the iron value was within the recommended level. The molar ratio of phytate and the three minerals were within the recommended value for better absorption. Water solubility index increased as the proportion of legume increased from $15 \%$ to $25 \%$ then decreased as legume increased to $35 \%$. B1 revealed significantly higher viscosity values $(248.43 \pm 3.35 \mathrm{cP})$ and viscosity decrease as the proportion of legume increased. Based on 10 nutritional and functional criteria, B3 possess the most desirable among the studied blends.
\end{abstract}

Key words: Cereal-legume blend, proximate composition, anti-nutrient, phytate/mineral molar ratio

DOI: http://dx.doi.org/10.4314/ejst.v10i2.3

\section{INTRODUCTION}

Malnutrition is a disparity between the amount of food and other nutrients that the body needs and the amount that it is receiving. In the developing world two-third of child mortality and morbidity is attributable to malnutrition. The prevalence of child malnutrition is extremely high in Ethiopia (38\% stunted, 24\% underweight and 10\% wasted) (EDHS, 2016). Critically important period of tackling malnutrition is the period of complementary feeding when foods of low nutrient density begin to replace breast milk and rates of diarrheal illness caused by food contamination are at their highest (Brown et al., 1998; World Bank, 2005). Children aged 6-24 months are at the highest risk of malnutrition mainly due to sub-optimal complementary feeding practice. As a result, they fail to attain their full potential of growth and development, suffer long-term deprivation of energy, nutrients, and consequently chronic protein energy malnutrition (PEM), often accompanied by micronutrient deficiencies. The period 6-24 months of age is one of the

*Corresponding author: hellenwalle@yahoo.com

(C) This is an Open Access article distributed under the terms of the Creative Commons Attribution License (http://creativecommons.org/licenses/CC BY4.0). 
most critical periods in the growth of the infant. At this age, their demand for nutrients relative to their body size is high. However, there are limitations in the quality and quantity of available complementary foods (World Bank, 2005).

Nutritionally balanced complementary feeding is an essential element in taking care of young children. However, due to high price of commercially available complementary foods families in Ethiopia habitually prepares complementary food from locally available raw materials. Traditional complementary foods in the developing countries are known to be of low nutritive value and are characterized by low protein, low energy density and high bulk, mainly because they are cereal-based (Dooshima et al., 2015). Complementary foods, especially prepared for the infant, should be blended with cereal and legume in order to get high energy, protein and micro-nutrient. However, in Ethiopia more than two third $(69.0 \%)$ of the complementary food is made up of wheat or teff and preparation of complementary foods made from mixed legumes and cereals is rare (AAU, 2010). Gibson et al. (2010) reported that such cereal-based complementary diets are characterized by poor micronutrient bioavailability notably of iron, zinc, and calcium as well as poor content and digestibility of protein. As a result of monotonous nature and poor texture of the complementary food during preparation as well as high content of anti-nutrient in commonly used cereals, the energy density and micronutrient content of complementary food used in Ethiopia is insufficient to cover the nutritional needs for child.

Appropriate consistency/texture of complementary foods is an important aspect of optimal infant and young children feeding. Given the low gastric capacity of children and the inability of the child to digest viscous foods, complementary food at early period of supplementary feeding is supposed to be semi-solid (Brown et al., 1998). However, the consistency of complementary food in Ethiopia is poor mainly because its preparation does not use technologic treatment. Specifically, $42.7 \%$ of all foods were identified as solid while $37.8 \%, 17.5 \%$ and $2.0 \%$ were described as having "thick like porridge", "thin like gruel" and "thinner than gruel, respectively (AAU, 2010).

FAO/WHO/UNICEF (1971) emphasised the use of local foods formulated at home guided by the following principles: (i) High nutritional value to supplement breastfeeding, (ii) Acceptability, (iii) Low price, and (iv) Use of local food materials (Dewey and Brown, 2003; Pelto et al., 2003). Moreover, for effective use and acceptance of complementary foods by consumers, it is desirable to study the impact of the process and blends on functional property of the products (Brou et al., 2013).

Therefore, this research was conducted to investigate the effect of different cereal-legume blending ratios on nutritional quality (proximate, mineral, anti-nutritional factors and phytate/ mineral molar ratio as a proxy indicator of mineral bioavailability) and functional property of the different blends, to choose the best blend based on selected nutritional profiles.

\section{MATERIALS AND METHODS}

\section{Sample Preparation and Experimental Design}

The cereal (maize, wheat and barley) and legume (chick peas, soybean and lentil) were cleaned manually and washed in 5\% (w/v) sodium chloride $(\mathrm{NaCl})$. The cereal was steeped in potable water 
at room temperature in grains to water ratio of $1: 3$ $(\mathrm{w} / \mathrm{v})$ in a plastic container by changing the water in every 3 hours for a total period of 9 hours. After which the cereal was drained. The cereal and legume were cleaned, minimally roasted (until it develops a golden colour), dehulled, milled and sifted through a fine mesh separately.

A single-factor experiment with three levels of the factor (cereal: legume ratio 85:15, 75:25 and $65: 35$ coded as B1, B2 and B3 respectively) selected from the most commonly used cereal: legume ratios used by different projects was used to prepare complementary foods. The experiment was completely randomized with two replications. The study was conducted at food research laboratory of Bahir Dar Institute of Technology, Ethiopia.

\section{Analysis and Measurement}

\section{Proximate, mineral, anti-nutritional factor composition analysis and phytate/mineral molar ratio determination}

Proximate composition (namely; moisture content, crude fat, fibre and ash content, crude protein content) analysis was determine in duplicate by using standard procedures of Association of Official Analytical Chemists (AOAC, 2005) and total carbohydrate was calculated by difference i.e. Total carbohydrates $[\%]=100-[\%$ Moisture $+\%$ Protein $+\%$ Fat $+\%$ Ash]. Gross energy was determined by calculation from fat, carbohydrate and protein contents using the Atwater's conversion factor with the following equation: (9 $* \%$ fat $)+(4 * \%$ protein $)+(4 * \%$ carbohydrate $)$ and expressed in kilocalories (kcal) (Atwater and Benedict, 1902).

Calcium, iron, and zinc content were determined in duplicate using an Atomic Absorption
Spectrophotometer. After removal of organic materials by dry ashing, the residue was dissolved in dilute sulphuric acid. The solution was sprayed into the flame of Atomic Absorption Spectrophotometer (ICP-Spectroscopy: "ULTIMA-2") and the absorption of the metal to be analyzed was measured at a specific wavelength.

Mineral content $\left(\frac{\mathrm{mg}}{100 \mathrm{~g}}\right)=\frac{[(a-b)+\mathrm{v}]}{10 \mathrm{~W}}$

Where: $\mathrm{W}=$ weight $(\mathrm{g})$ of samples; $\mathrm{V}=$ volume $(\mathrm{V})$ of extract; $\mathrm{a}=$ concentration $(\mu \mathrm{g} / \mathrm{ml})$ of sample solution; $\mathrm{b}=$ Concentration $(\mu \mathrm{g} / \mathrm{ml})$ of blank solution.

Phytic acid content was determined as described by Wheeler and Ferrel (1971). Briefly, the sample $(0.2 \mathrm{~g})$ was extracted four times for $40 \mathrm{~min}$ with $3 \%$ Trichloracetic acid (TCA) and then centrifuged for $30 \mathrm{~min}$ at $5000 \mathrm{rpm}$. Aliquot $(10 \mathrm{~mL})$ of the supernatant was precipitated with $4 \mathrm{~mL} \mathrm{FeCl}_{3}$ solution containing $0.2 \% \mathrm{FeCl}_{3}$ in $3 \% \mathrm{TCA}$. The solution was heated for $45 \mathrm{~min}$ in a water bath (Aston VII) at $100^{\circ} \mathrm{C}$ and centrifuged at $5000 \mathrm{rpm}$ for $15 \mathrm{~min}$. The $\mathrm{Fe}(\mathrm{OH})_{3}$ obtained was dissolved in $40 \mathrm{~mL}$ of hot $3.2 \mathrm{~N} \mathrm{HNO}_{3}$ and the Iron determined calorimetrically (Jenway Ltd Felsted, Dunmow, Essex CM6 3LB model 6051). The absorbance of the solution was read in a spectrophotometer (Jenway Ltd Felsted, Dunmow, Essex CM6 3LB model 6300) at $480 \mathrm{~nm}$ against a reagent blank for each set of sample. The iron content was calculated from a standard curve. Phytate phosphorus was calculated from determination assuming 4:6 Iron: Phosphorus molecular ratio. Phytic acid content was determined by multiplying the phytate phosphorus content by a constant factor of 3.55 based on the empirical formula $\mathrm{C}_{6} \mathrm{P}_{6} \mathrm{O}_{24} \mathrm{H}_{18}$. 
For the determination of tannin content, $0.2 \mathrm{~g}$ of the milled sample was weighed into a flask and $10 \mathrm{ml}$ of $4 \%$ methanol was pipetted and the flask was closed with paraffin. The sample was shake for 20 minutes on a wrist action Shaker, centrifuged for 10 minute (4500 revolution per minutes). Absorbance of the standard solution, sample extract and sample blank were taken 20 minutes after incubation in the spectrophotometer at $500 \mathrm{~nm}$.

$$
\% \text { Tannin }=\frac{\boldsymbol{A} * \text { Cstd }}{A \text { std }}
$$

Where: $\mathrm{AU}=$ Absorbance of unknown; Cstd $=$ Concentration of Standard and AStd = Concentration of Standard.

Among the techniques used to determine the bioavailability of minerals in the human body, measuring the molar ratio of phytate and minerals in the food is suggested by Morris and Ellis (1989). The suggested desirable molar ratios for mineral absorption are phytate:iron $<1$ (Hallberg et al., 1989), phytate:zinc < 15 (Turnlund et al., 1984; Sandberg et al., 1987; Morris and Ellis, 1989); phytate:calcium < 0.24 (Morris and Ellis, 1985). The mole of phytate and minerals was determined by dividing the weight of phytate and minerals with its atomic weight (phytate: $660 \mathrm{~g} / \mathrm{mol}$; Fe: 56g/mol; Zn: 65g/ mol; Ca: $40 \mathrm{~g} / \mathrm{mol})$. The molar ratio between phytate and mineral was obtained after dividing the mole of phytate with the mole of minerals.

\section{Functional properties}

Water absorption index (WAI) of the sample flour was determined in duplicate as per the method of Anderson (1969). Sample of $1.25 \mathrm{~g}$ was placed in $40 \mathrm{ml}$ centrifuge tube and suspended in $15 \mathrm{ml}$ distilled water. The sample was incubated by using a shaker water bath (DKZ-1) at about $25^{\circ} \mathrm{Cfor}$ 30 minutes and was centrifuged at 3000rpm for 5 minutes. Mass of the sample was determined before and after the decantation of the clear supernatant of centrifugation (L-530 tabletop). The WAI was calculated as grams of absorbed water per gram of dry sample mass $(1.25 \mathrm{~g})$. The clear supernatant of the centrifugation was transferred into pre-dried $\left(105^{\circ} \mathrm{C}\right)$ and weighed glass baker (about $50 \mathrm{ml}$ ) for the estimation of the water solubility index (WSI).

The supernatant preserved from WAI measurement was evaporated at $105^{\circ} \mathrm{C}$ overnight. The WSI was calculated as a ratio of dry residue to the original mass $(1.25 \mathrm{~g})$ used to estimate WAI and the result was expressed as percentage.

The viscosity of cooked paste was determined with a VISCO STAR PLUS H model. A 10\% slurry (dry matter basis) of each flour was prepared with $200 \mathrm{ml}$ distilled water and the slurry was heated uniformly from $25^{\circ} \mathrm{C}$ to $95^{\circ} \mathrm{C}$ and held for $15 \mathrm{~min}$ and cooled to $50^{\circ} \mathrm{C}$. Then viscosity was determined after cooling to $50^{\circ} \mathrm{C}$ (Mbata et al., 2009).

\section{Data handling and statistical analysis}

Summary statistics (mean and standard deviation) was computed for dependent variables. In order to find differences between blends, the proximate composition, mineral content, anti-nutritional composition, functional properties (WAI, WSI and Viscosity) were determined and Phytate/ Mineral molar ratio were calculate in duplicate per sample (Four times per treatment) and submitted to General Linear Model (GLM) procedure using SPSS 20.0 statistical software package. ANOVA was used for comparison of means. Significance 
was accepted at 0.05 level of probability $(\mathrm{p}<0.05)$. Mean separation was performed by least significant difference (LSD) for multiple comparisons of means.

Additionally, a ranking system using ten nutritional and functional criteria's related with appropriate complementary food characteristics and major forms of malnutrition (namely, protein energy malnutrition and micronutrient deficiency) was devised to determine the optimal blend combination according to the modified method of Griffith et al. (1998) (Table 4). Based on the relative importance and interrelationship of those criteria, ranking was reported on an equal weight basis. The three blends were ranked from 1 (best) to 3 (worst) to objectively determine the best complementary blend. The blend yielding the lowest score was considered to possess the most suitable nutritional and functional characteristics.

\section{RESULTS AND DISCUSSION}

\section{Effect of different Cereal: Legume Blending} Ratio on Proximate Composition of

\section{Complementary Food}

Mean and standard deviation (SD) of the proximate composition measurements of the complementary food products at different blending ratio and recommended proximate composition values as per FAO/WHO (1991) are given in Table 1.

The three blending ratios didn't show significant difference with respect to moisture content. The moisture content of the formulated complementary food samples was $6.51 \pm 0.08$ (B1), $6.54 \pm 0.06$ (B2) and the highest value $6.58 \pm 0.08$ (B3) was observed as the proportion of legume increase. In all blending ratios, the value was higher than the recommended value of Codex Alimentarius $(\leq 5 \%)$ but within the recommended moisture content range (5-10) recommended by Protein Advisory

Table 1: Effect of blending ratio on proximate compositions of formulated product

\begin{tabular}{|c|c|c|c|c|}
\hline \multirow{2}{*}{ Proximate compositions } & \multicolumn{3}{|c|}{ Samples $($ mean \pm SD) } & \multirow{2}{*}{$\begin{array}{l}{ }^{*} \text { Recommended } \\
\text { values }(\mathrm{g} / 100 \mathrm{gm})\end{array}$} \\
\hline & $\mathrm{B}_{1}$ & $\mathrm{~B}_{2}$ & $\mathrm{~B}_{3}$ & \\
\hline Moisture content $(\%)$ & $6.51 \pm 0.08^{\mathrm{a}}$ & $6.54 \pm 0.06^{\mathrm{a}}$ & $6.58 \pm 0.08^{\mathrm{a}}$ & $\leq 5$ \\
\hline Ash content $(\%)$ & $2.04 \pm 0.03^{\mathrm{a}}$ & $2.18 \pm 0.02^{b}$ & $2.27 \pm 0.04^{\mathrm{c}}$ & $\leq 3$ \\
\hline Crude Protein (\%) & $14.64 \pm 0.02^{\mathrm{a}}$ & $15.73 \pm 0.03^{b}$ & $16.50 \pm 0.02^{\mathrm{c}}$ & $\geq 15$ \\
\hline Crude fat (\%) & $5.80 \pm 0.06^{\mathrm{a}}$ & $6.16 \pm 0.11^{\mathrm{b}}$ & $8.22 \pm 0.07^{\mathrm{c}}$ & $10-25$ \\
\hline Crude fiber $(\%)$ & $2.01 \pm 0.02^{\mathrm{a}}$ & $2.24 \pm 0.03^{\mathrm{b}}$ & $2.61 \pm 0.01^{\mathrm{c}}$ & $\leq 5$ \\
\hline Carbohydrate (\%) & $71.00 \pm 0.08^{\mathrm{a}}$ & $69.39 \pm 0.08^{\mathrm{b}}$ & $66.43 \pm 0.15^{\mathrm{c}}$ & $64 \pm 4$ \\
\hline Energy (kcal/100g) & $394.77 \pm 0.48^{\mathrm{a}}$ & $395.94 \pm 0.27^{b}$ & $405.76 \pm 0.12^{\mathrm{c}}$ & $400-425$ \\
\hline
\end{tabular}

Means followed by different superscripts within a row show statistically significant $(\mathrm{p}<0.05)$ differences.

*FAO/WHO (1991) (CODEX CAC/GL 08. 1991): Codex Alimentarius: Guidelines on formulated supplementary foods for older infants and young children. 
Group (PAG, 2002) and Standard Organization of Nigeria (SON, 1989). In the present study, the moisture content of the blends was similar to the finding of Mohamed and Huiming (2007). Scientific studies reported on the importance of low moisture content in complementary foods, especially to increase the nutrient composition (Amankwah et al., 2009) and shelf life of the product (Kikafunda, 2006). It is evident that the low moisture content of food products inhibits biochemical activities of invading microorganisms, and thereby prevents food spoilage during storage (Kikafunda, 2006).

Mean separation result showed that there was a significant difference in protein content among all blends where B3 (16.50 \pm 0.02$)$ revealed significantly $(\mathrm{p}<0.05)$ higher content as compared to B2 $(15.73 \pm 0.03)$ and B1 (14.64 \pm 0.02$)$. This observation could be attributed to the fact that protein content of cereal-legume combination or blending of two or more plant-based food materials is better than those produced from a single plant based food materials (Achi, 2005; Solomon 2005; Wakil and Onilude, 2009). Protein contents of formulated complementary food with $25 \%$ and $35 \%$ legume were within the recommended level of FAO/WHO (1991). Whereas complementary food formulated with $15 \%$ legume didn't meet the protein requirement of formulated complementary foods for older infants and young children. However, WHO (2009) suggested that while protein is needed for growth, high protein levels above $15 \%$ may increase renal solute load and interfere with appetite.

Ash content represents the total mineral content in foods. All blends varied significantly $(P<$ 0.05) in ash content resulting from differences in amount among individual ingredients. Ash content was significantly higher in B3 $(2.27 \pm 0.04)$ than B2 (2.18 \pm 0.02$)$ and B1 $(2.27 \pm 0.04)$ and the values were within the reference value for all the blends. This high concentration of ash in B3 could be linked to the addition of legumes during formulation. Gibson et al. (1998) also demonstrated that legumes are rich in minerals. Therefore, supplementing cereals with these foods could lead to higher mineral content.

The crude fibre content of the three blends also showed significant difference where the highest value was observed in B3 $(2.61 \pm 0.01)$. The crude fibre content of infant food is supposed to be low (Amuna, 2000; Olorunfemi et al., 2006), as food with high fibre content tends to cause difficulties in digestion of protein and mineral absorption. The observed low fibre content of the three blends were within the recommended values of $\mathrm{FAO} / \mathrm{WHO}$ (1991) which enable the children to consume most of the food samples so as to meet their daily energy and other vital nutrient requirements (Eka and Edijala, 1972).

The difference in fat content among the three blends were significant $(\mathrm{P}<0.05)$. And the highest value was observed for B3 (5.80 \pm 0.06$)$ with high proportion of legume (35\%) than B2 $(25 \%)$ and B1 (15\%). However, the fat content in all the three blends do not meet the recommended value $10-$ $25 \%$ of FAO/WHO (1991). Comparatively higher fat content of formulated samples was reported by Lalude and Fashakin (2006) for sorghum and oil seeds blend (9.87\%) and by Amankwah et al. (2009) for fermented maize, rice, soybean and fishmeal blend (8.75-9.38\%). This finding signifies the importance of including legumes and oil seeds which are rich in fat content to meet the fat requirement of infants and young children living in resource-poor households in low income countries 
where consumption of animal-source foods is often low due to economic or religious reasons.

The carbohydrate content of the three blends showed significant $(\mathrm{P}<0.05)$ difference where the highest value was observed in B1 $(71.00 \pm 0.08)$ but it decreased with an increase in legume ratio. However, all the blends met the recommended value $(64 \pm 4 \%)$ by FAO/WHO (1991).

The energy in an infant's diet is provided by protein, fat and carbohydrates (Amankwah et al., 2009). There was significant $(\mathrm{P}<0.05)$ difference in the energy content of the three blends where the highest $(405.75 \pm 0.13 \mathrm{kcal} / 100 \mathrm{gm})$ was measured in B3. This could be probably due to the relatively high fat and protein content of the legumes blended in greater proportion (35\%). Among the blends only B3 met the recommended value of 400$425 \mathrm{kcal}$ by $\mathrm{FAO} / \mathrm{WHO}$ (1991). Brown et al. (1998) recommended that foods fed to infants and children should be energy-dense as low-energy foods tend to limit total energy intake and the utilization of other nutrients.

\section{Effect of different cereal: legume blending ratio on mineral content, anti-nutritional factors and phytate: minerals molar ratio of complementary foods}

Table 2 summarizes data on the iron, zinc, calcium, tannin and phytate concentrations of the three complementary food blends. Corresponding phytate/mineral molar ratios are also given.

All blends significantly $(\mathrm{p}<005)$ varied in $\mathrm{Ca}^{+2}$, $\mathrm{Fe}^{+3}$ and $\mathrm{Zn}^{+}$content. Calcium and zinc content of the blends increased as the proportion of legumes in the blend increases. The finding also showed that the calcium and zinc content of the three blends didn't meet the recommended value by FAO/WHO (1991) for infant formulas. In contrast, iron content of the blend decreased in response to an increase in the proportion of legume and the iron content of the three blends was within the recommended value $(16 \mathrm{mg} / 100 \mathrm{~g})$ of $\mathrm{FAO} / \mathrm{WHO}$ (1991). Gibson et al. (2010) also reported these same mineral deficits earlier for infants and young children consuming the indigenous complementary foods. Such deficits in iron, zinc, and calcium can have far-reaching adverse consequences on growth, health, and cognitive development during childhood. The present study demonstrated the importance of fortification of cereal: legume based complementary foods with calcium and zinc or enriching the diet with animal source ingredients during preparation of the food to ensure it meet the FAO/WHO (1991) estimated needs for zinc and calcium for infants and young children.

Anti-nutrient composition result showed that phytate and tannin concentration of the three blends didn't show significant difference $(\mathrm{p}>0.05)$. Poor mineral content of plant-based complementary diets exacerbated in part by poor bioavailability, especially when the complementary foods are based on unrefined cereals and legumes which have a high content of phytate, a potent inhibitor of mineral absorption (Gibson et al., 2006). As a result, interpreting the level of phytate as phytate/mineral molar ratio (proxy indicator of bioavailability) is suggested by most studies.

As indicated in Table 2 the three blends had phytate/zinc molar of 6.8 (B1), 6.3 (B2) and 5.8 (B3). Considering phytate/zinc molar ratio $<15$ as desirable limit for absorption, phytate:zinc molar ratios of all the blends were low thus met the desired level. The contribution of the low phytate/ zinc molar ratio to bioavailability of Zinc was 
Table 2: Iron, zinc, Calcium, Phytate, Tannin content and Phytate/Mineral Molar Ratios of the three blends

\begin{tabular}{|c|c|c|c|c|}
\hline \multirow{2}{*}{$\begin{array}{l}\text { Mineral, Phytate, } \\
\text { tannin content and } \\
\text { phytate/mineral } \\
\text { molar ratio }\end{array}$} & \multicolumn{4}{|c|}{ Cereal: Legume Blending Ratios } \\
\hline & B1 & B2 & B3 & $\begin{array}{l}\text { Recommended } \\
\text { values }(\mathrm{mg} / 100 \mathrm{gm})\end{array}$ \\
\hline $\mathrm{Ca}(\mathrm{mg} / 100 \mathrm{~g})$ & $32.81 \pm 0.04^{\mathrm{a}}$ & $43.8 \pm 0.02^{b}$ & $54.75 \pm 0.01^{\mathrm{c}}$ & $500 *$ \\
\hline $\mathrm{Fe}(\mathrm{mg} / 100 \mathrm{~g})$ & $35.17 \pm 0.02^{\mathrm{a}}$ & $27.04 \pm 0.01^{b}$ & $24.69 \pm 0.04^{\mathrm{c}}$ & $16^{*}$ \\
\hline $\mathrm{Zn}(\mathrm{mg} / 100 \mathrm{~g})$ & $1.92 \pm 0.05^{\mathrm{a}}$ & $2.06 \pm 0.06^{\mathrm{b}}$ & $2.25 \pm 0.04^{\mathrm{c}}$ & $3.2 *$ \\
\hline Phytate (mg/100g) & $132.34 \pm 0.15^{\mathrm{a}}$ & $132.38 \pm 0.12^{\mathrm{a}}$ & $132.39 \pm 0.25^{\mathrm{a}}$ & ---- \\
\hline Tannins(mg/100g) & $4.57 \pm 0.56^{\mathrm{a}}$ & $4.56 \pm 0.25^{\mathrm{a}}$ & $4.52 \pm 0.09^{\mathrm{a}}$ & ---- \\
\hline Phytate/Zn* & 6.8 & 6.3 & 5.8 & $<15^{* *}$ \\
\hline Phytate/Fe* & 0.32 & 0.4 & 0.45 & $<1 * *$ \\
\hline Phytate/Ca* & 0.23 & 0.18 & 0.14 & $<0.24 * *$ \\
\hline
\end{tabular}

All values are means of four measurements $(n=4) \pm$ standard deviation.

Means followed by different superscripts within row show statistically significant $(\mathrm{p}<0.05)$ differences.

*FAO/WHO (CODEX CAC/GL 08. 1991) * ** Gibson et al. (2010)

justified by Hotz and Brown (2004), who reported zinc absorption to be $18 \%$ and $25 \%$ for adult males and females, respectively if the phytate/zinc molar ratio is $>18$, whereas for diets with phytate/zinc molar ratios between 4 and 18 the corresponding estimates for adults are $26 \%$ and $34 \%$, respectively. Gibson et al. (2010) explained the reduction in Phytate/zinc molar ratio is due to the degradation of phytate in cereal and/or legume and linked with significant increases of Zinc. Similarly, all the complementary food blends had phytate/iron molar ratios $<1$ and phytate/calcium molar ratio $<0.24$, which is desirable for better iron and calcium bioavailability respectively. Phytate/mineral ratio of the three minerals indicates that zinc, iron and calcium absorption was unlikely to be markedly compromised by phytate. The probable reason for these low phytate/ mineral molar ratios may be the effect of soaking, roasting, dehulling used in the processing of the three blends. Gibson et al. (2006) reported that molar ration between phytate and mineral improved by enriching complementary foods with animal-source foods or practice processing methods such as roasting, germination and fermentation.

\section{Effect of blend ratio on functional property of complementary foods}

The functional properties of the food materials are very important for the suitability of the diet, particularly, for the growing children. Functional properties (WAI, WSI and Viscosity) of the formulated complementary foods are presented in Table 3. Water absorption index gives an indication of the ability of flour to absorb water and the amount of water available for gelatinization depends on the availability of hydrophilic groups which bind water molecules (Kulkarni et al., 
2002). The water absorption index of B3 (1.64 $\pm 0.01)$ was significantly $(p<0.05)$ higher than $B 2$ $(1.59 \pm 0.01)$ and $\mathrm{B} 1(1.60 \pm 0.04)$ but there was no significant difference between WAI values of B1 and B2. As cited in Brou et al., 2013; Gamel et al. (2006) explained that an increase of WAI could be attributed to an increase in protein content and Kinsella (1976) explained that, the polar amino acid residues of proteins have an affinity for water molecules that explained easily water absorption of products having high amount of protein. According to PAHO/WHO (2003), appropriate complementary food is the one which produce a gruel or porridge that is neither too thick for the infant to consume nor so thin that energy and nutrient density are reduced. Therefore, low water absorption capacity is desirable in complementary foods for making semi-solid porridge with high caloric density per unit volume.

Water solubility index (WSI) is used as a measure for starch degradation; it means that at lower WSI there is minor degradation of starch and such condition leads to less numbers of soluble molecules in the formulate (Hernandez-Diaz et al., 2007). The WSI of complementary food with cereal legume blending ratio of 85:15 (B1), 75:25
(B2) and 65:35 (B3) were $8.85 \pm 0.05,8.91 \pm 0.08$ and $8.29 \pm 0.04$, respectively. WSI increase as the proportion of legume increase and blend with cereal:legume ration of 75:25 (B2) revealed significantly higher WSI and WSI decreased as the proportion of protein increased to $35 \%$ (B3) of the blend. This finding concedes with Brou et al. (2013) who reported an increase in WSI as the proportion of legumes increased from 0 to 30 followed by a decrease when the proportion of legume increased to $45 \%$ of the blend.

The viscosity characteristics of the complementary foods blended at different cereals to legumes ratio shows that, the blend with high carbohydrate content B1 revealed significantly higher viscosity values $(248.43 \pm 3.35)$ and viscosity decrease as the proportion of legume in the blend increased. This relation suggests a higher viscosity can be expected from blends with a lower fat and protein content. Hellström et al. (1981) showed a similar correlation in complementary gruels made from wheat and field pea flour. A larger percentage of fat decreases the carbohydrate content, reducing the amount of starch available for gelatinization. Jacobs et al. (1995) related viscosity to the extent of starch granule swelling. Low viscosity

Table 3: Effect of blending ratio on functional properties (WAI, WSI and Viscosity) of complementary foods

\begin{tabular}{|c|c|c|c|}
\hline \multirow{2}{*}{ Blends } & \multicolumn{3}{|c|}{ Functional properties } \\
\hline & WAI & WSI & Viscosity \\
\hline $\mathrm{B} 1$ & $1.60 \pm 0.04^{\mathrm{a}}$ & $8.85 \pm 0.05^{\mathrm{a}}$ & $248.43+3.35^{\mathrm{a}}$ \\
\hline B2 & $1.59 \pm 0.01^{\mathrm{a}}$ & $8.91 \pm 0.08^{\mathrm{a}}$ & $232.12+2.81^{b}$ \\
\hline B3 & $1.64 \pm 0.01^{b}$ & $8.29 \pm 0.04^{b}$ & $228.45+3.15^{\mathrm{b}}$ \\
\hline
\end{tabular}

All values are means of four measurements $(n=4) \pm$ standard deviation

Means followed by different superscripts within column show statistically significant $(p<0.05)$ differences 
of a cereal-based gruel is advocated for infant feeding. The low viscosity allows flexibility for manipulating the product consistency by increasing the solids concentration. This also provides a simple, inexpensive means for increasing the product's nutrient density.

\section{Determining optimal complementary food blend}

Table 4: Ranking of complementary food blends for determining optimal nutritional and functional profile

\begin{tabular}{llll}
\hline \multirow{2}{*}{ Nutritional Profile } & \multicolumn{3}{l}{ Cereal: Legume blending ratio } \\
\cline { 2 - 4 } & $\mathrm{B} 1(85: 15)$ & $\mathrm{B} 2(75: 25)$ & $\mathrm{B} 3(65: 35)$ \\
\hline Protein (\%) & 3 & 2 & 1 \\
Energy (kcal/100gm) & 3 & 2 & 1 \\
Ash (mg/100gm) & 3 & 2 & 1 \\
Fiber & 1 & 2 & 3 \\
Tannin (mg/100gm) & 3 & 2 & 1 \\
Phytate:Zinc Molar Ratio & 3 & 2 & 1 \\
Phytate:Iron Molar Ratio & 1 & 2 & 3 \\
Phytate:Calcium Molar Ratio & 3 & 2 & 1 \\
WSI & 2 & 1 & 3 \\
Viscosity & 3 & 2 & 1 \\
Total Score & 25 & 19 & 16 \\
\hline
\end{tabular}

${ }^{*}$ Most desirable (1) to least desirable (3).

As indicated in Table 4 complementary food blended from $65 \%$ cereal and 35\% legume (B3) yielded the lowest total ranking scores. This blend was concluded to possess the most desirable nutritional and functional profiles among the blends studied.

\section{CONCLUSION}

The present study demonstrated that complementary food of high nutrient profile can be formulated from mixture of cereals and legumes. There was statistically significant difference among the Cereal: legume blends nutritional and functional qualities. The study revealed the protein, carbohydrate, iron and the energy content of the complementary food blend from $35 \%$ cereal and $65 \%$ legume is in the range of $\mathrm{FAO} / \mathrm{WHO}$ recommended daily intake for 6-23 months. However, the fat, calcium and zinc 


\section{REFERENCES}

AAU. (2010). Rapid Assessment of Communitybased Production of Complementary Food in Tigray, Amhara, Oromia and SNNP Regions. Final Report Submitted to UNICEF-Ethiopia Country Office.

Achi, O. K. (2005). The upgrading of traditional fermented foods through biotechnology. African Journal of Biotechnology 4: 375-380.

Amankwah, E. A., Barimah, J., Acheampong, R., Addai L.O and Nnaji, C. O. (2009). Effect of fermentation and malting on the viscosity of maize-soyabean weaning blends. Pakistan Journal of Nutrition 8(10): 1671-1675.

Amuna, P., Zotor, F., Sumar, S and Chinyanga, Y.T. (2000). The role of traditional cereal/ legume/fruit-based multi-mixes in weaning in developing countries. Journal of Nutrition and Food Science 30(3): 116-122.

Anderson, R. A., Conway, H. F., Pfeifer, V. F and Griffin, E. L. (1969). Gelatinization of corn grits by roll and extrusion cooking. Cereal Science Today 14:4-12.

AOAC. (2005). Official Methods of Analysis $16^{\text {th }}$ ed. Association of Official Analytical Chemists, Arlington V.A, pp/ 806-842.

Atwater, W. O and Benedict, F.G. (1902). A new respiratory calorimeter and experiments on the conservation of energy in human body II. Physical Review 9: 214-251.

Brou, K., N'Da-Kouassi, A. M., Kouadio, J. H., Guehi, T., N'Guessan, K. F and Gnakri, D. (2013). Biochemical characterization and functional properties of weaning food made from cereals (millet, maize) and legumes (beans, soybeans). Journal of Food Chemistry and Nutrition 01(01): 22-32.
Brown, K. H., Dewey, K. G and Allen, L. H. (1998). Complementary feeding of young children in developing countries: a review of current scientific knowledge. WHO, Geneva.

Dooshima, S., Michael, A. I and Dick I. G (2015). Nutritional evaluation of complementary food formulations from maize, soybean and peanut fortified with Moringa oleifera leaf powder. Food and Nutrition Sciences 6: 494-500.

EDHS(2016). Ethiopian Demographic and Health Survey, Key indicators Report. https:// dhsprogram.com/pubs/pdf/PR81/PR81.pdf (accessed on February 10, 2017).

Eka, O. U and Edijala J.K. (1972). Chemical composition of some traditionally prepared Nigerian foods. Nigerian Journal of Science 6: $157-162$.

FAO/WHO. (1991). Codex Alimentarius (CODEX CAC/GL 08): Guidelines on Formulated Supplementary Foods for Older Infants and Young Children. 4: FAO/WHO Joint Publications.

Gibson, R. S., Fergurson, E. L and Lehrfeld, J. (1998). Complementary foods for infant feeding in developing countries: their nutrient adequacy and improvement. European Journal of Clinical Nutrition 52: 764-770.

Gibson, R. S., Perlas, L and Hotz, C. (2006). Improving the bioavailability of nutrients in plant

foods at the household level. Proceedings of the Nutrition Society 65 (2):160-168.

Griffith, L. D., Castell-Perez, M. E and Griffith, M. E. (1998). Effects of blend and processing method on the nutritional quality of weaning foods made from selected cereals and legumes. Cereal Chemistry 75:105-112. 
Hellström, A., Hermansson, A. M., Karlsson, A., Ljungqvist, B., Mellander, $\mathrm{O}$ and Svanberg, U. (1981). Dietary bulk as a limiting factor for nutrient intake - with special reference to the feeding of pre-school children. Journal of Tropical Paediatrics 27:127-135.

Hernandez-Diaz, J. R., Quintero-Ramos, A., Barnard, $\mathrm{J}$ and Balandran-Quintana, R.R. (2007). Functional properties of extrudates prepared with blends of wheat flour/pinto bean meal with added wheat bran. Food Science and Technology International 13(4): 301-308.

Hotz, C and Brown, K. H. (2004). International Zinc Nutrition Consultative Group (IZiNCG) Technical Document \#1. Assessment of the risk of zinc deficiency in populations and options for its control. Food Nutrition Bull 25: 99-199.

Jacobs, H., Eerlingen, R. C., Clauwaert, W and Delcour, J. A. (1995). Influence of annealing on the pasting properties of starches from varying botanical sources. Cereal Chemistry 72:480-487.

Kikafunda, J.K., Abenakyo L and Lukwago F.B. (2006). Nutritional and sensory properties of high energy/nutrient dense composite flour porridges from germinated maize and roasted beans for child-weaning in developing countries: a case for Uganda. Ecology of Food and Nutrition 45:279-294.

Kinsella, J.E. (1976). Functional properties of proteins in foods: a survey. Food Science and Nutrition 7: 219-280.

Kulkarni, K.D., Kulkarni, D.N and Ingle, U.M. (2002). Sorghum malt-based weaning food formulations: Preparation, functional properties and nutritive value. Food and Nutrition Bulletin 13(4): 322-327.
Lalude, L.O and Fashakin, J.B. (2006). Development and nutritional assessment of a weaning food from sorghum and oil- seeds. Pakistan Journal of Nutrition 5:257-260.

Mbata, T. I., Ikenebomeh, M. J and Alaneme, J. C. (2009). Studies on the microbiological, nutrient composition and antinutritional contents of fermented maize flour fortified with bambara groundnut (Vigna subterranean L). African Journal of Food Science 3(6):165171.

Morris, E. R and Ellis, R. (1985). Bioavailability of dietary calcium-effect of phytate on adult men consuming non-vegetarian diets. In: ACS Symposium Series 75: Nutritional Bioavailability of Calcium (Kies $\mathrm{C}$ ed.). American Chemical Society, Washington, DC, USA.

Morris, E. R and Ellis, R. (1989). Usefulness of the dietary phytic acid/zinc molar ratio as an index of zinc bioavailability to rats and humans. Biological Trace Element Research 19:107-117.

Olorunfemi, O.B., Akinyosoye, F. A and Adetuyi, F. C. (2006). Microbial and nutritional evaluation of infant weaning food from mixture of fermented food substrates. Research Journal of Biological Science 1:20-23.

PAG. (2002). Protein Advisory Group of United Nations. PAG guideline No.8, Protein rich mixtures for use as weaning foods. New York, FAO/WHO/UNICEF.

PAHO/WHO (2003). Guiding principles for complementary feeding of the breastfed child. Pan American Health Organization/ World Health Organization. http://iris.paho.org/ xmlui/handle/123456789/752 (accessed February 10, 2017). 
Sandberg, A. S., Anderson, H., Carlesson, N. G and Sandstrom, B. (1987). Degradation products of bran phytate formed during digestion in the human small intestine: effects of extrusion cooking on digestibility. Journal of Nutrition 117:2061-2065.

Solomon, M. (2005). Nutritive value of three potential complementary foods based on cereals and legumes. African Journal of Food Nutrition 5:1-14.

SON. (1989). Standard for Foods for Infants and Children: Infant formula Nigerian Industrial Standards 255, UDC: 61221:641.

Turnlund, J. R., King, J. C., Keyes, W. R, Gong, B and Michel, M.C. (1984). A stable isotope study of zinc absorption in young men: effects of phytate and cellulose. American Journal of Clinical Nutrition 40:1071-1077.

Wheeler, E. I and Ferrel, R. E. (1971). A method for phytic acid determination in wheat and wheat fractions. Cereal Chemistry 48: 312320 .

WHO. (2009). Proceedings of the WHO UNICEF WFP UNHCR informal consultation on the management of moderate malnutrition in under-5 children. Geneva, Oct. 2008. Food and Nutrition Bulletin 30(3): S464474.

World Bank. (2005). Repositioning Nutrition as Central to Development: A Strategy for Large scale action. The World Bank press. http://www. unhcr.org/45f6c4432.ndf (accessed on February 10, 2017). 